\title{
Algorithm Design to Determine Possibility of Student Graduate Time in Student Grade Recapitulation Application
}

\author{
Marliana Budhiningtias Winanti ${ }^{1}$, Umi Narimawati ${ }^{2}$, Suwinarno Nadjamudin ${ }^{3}$, Hendar Rubedo $^{4}$, Syahrul Mauluddin $^{5} *$ \\ Department Information System, Universitas Komputer Indonesia, Bandung, Indonesia ${ }^{1}$ \\ Department Management, Universitas Komputer Indonesia, Bandung, Indonesia ${ }^{2}$ \\ Department Informatic Engineering, International Woman University, Bandung, Indonesia ${ }^{3}$ \\ Department Business Administration, International Woman University, Bandung, Indonesia ${ }^{4}$ \\ Department Informatic Management, Universitas Komputer Indonesia, Bandung, Indonesia ${ }^{5}$
}

\begin{abstract}
This study aims to create an algorithm model to determine the potential time for student graduation to be applied to the grade recapitulation information system at XYZ University Information System Study Program. The XYZ University Information System Study Program already has a grade recapitulation information system, but the grade recapitulation information system has not been able to provide potential information about when a student can graduate from college. Information about probability graduating from college is very important as evaluation material in providing direction to students as an effort to achieve graduate on time. The more students who graduate on time, it can help increase the value of accreditation. The existing grade recapitulation information system can only display a history of grades and courses that have been taken by a student, so that the guardian lecturer has difficulty checking the courses that have not been taken by the student guidance and difficulty obtaining information when the student's guidance can graduate from college. In this study, an algorithm model was used to calculate the student's graduate time based on the calculation and mapping of subjects that had not been taken and had not yet passed. Based on the test results, the average time needed to determine student graduation time is 0.165 seconds.
\end{abstract}

\section{Keywords-Algorithm; graduate; subject; grade}

\section{INTRODUCTION}

Nowadays graduate on time is one of the most important concerns in higher education [1], so procedure or policy are needed to give a significant impact on graduation on time [2]. Graduating on time is one of the aspects of accreditation assessment in Indonesian tertiary institutions, especially in assessing the effectiveness and productivity of education. The more students graduate on time, the better the educational effectiveness and productivity of the study program will be.

The information systems study program at XYZ University in Indonesia has a relatively low graduate rate on time. The annual passing rate on time is below 50\%. The low level of graduation time is due to the absence of supervision, especially for students who have the prospect to graduate overdue. The information system study program already has an executive information system that can provide information on the number of alumni who graduate on time and late graduate, but cannot provide information on active students who have the potential to graduate not on time. Information on the potential for graduating from college is very important as evaluation material in providing direction to students to graduate on time.

Based on the aforementioned problems, to increase the number of students who graduate on time, there is a need for a monitoring mechanism for students, especially students who have the probability to graduate not on time so that the guardian lecturers can provide direction and strategy in achieving graduate on time.

The purpose of this research is to design an algorithm to determine the possibility of students to graduate based on courses that have not been taken or have not passed. Research to determine the probability of graduate from college has been carried out by many other researchers through application of predictive algorithms such as the chaid method, naïve Bayes, decision tree, SVM algorithm, random forest, logistic regression and artificial neural network algorithms. However, in contrast to this research, this research will create an algorithm to calculate the possibility of graduate from college based on data subjects' grade that have not passed or have not been taken. Not based on a database of graduated student's grade. The research will provide information on how many more semesters must be taken, what courses can be taken each semester and whether they have the potential to graduate on time or not on time.

\section{LITERATURE REVIEW}

\section{A. Related Work}

Previous researchers have conducted several studies related to problem of graduate on time. Among them are those who conduct research to determine the factors inhibiting students from graduate on time and some are conducting research to predict graduation on time. However, based on the search and review, result of existing research has not been found similar to current research.

In 2013, Ni Komang Deby Ariani et al. Conducting research to determine the inhibit factors for graduates on time based on gender, major, entry route, origin area, origin school,

*Corresponding Author 
and duration of final assignment. The conclusion of this study is that student graduation based on GPA with satisfactory category, it is found that there are no factors (independent variables) that affect student graduation time, while for student graduate based on GPA with very satisfying category, the factors that influence the time of graduation are gender, department, origin area, and duration of final assignment. Furthermore, for student graduates based on the GPA with the honors category, the factors that influence are origin area and the length of work on the final project [3]. In 2017, Widarto conducted research to determine the inhibiting factors seen from the problems in the final project process. Can be concluded that the cause of not graduate on time is the long distance to campus for guidance, still attending college, already have a job, less active lecturers, less conducive housing, and less intensive guidance [4].

To predict student graduation, many researchers apply data mining techniques with chaid method [5], naïve bayes [6], decision tree [7], SVM algorithm [8][9], random forest [10], artificial neural network algorithms [11], etc. Those studies using grades of graduate students then based on the data mining process the prediction results of student graduation are obtained. In contrast to this research, the prediction of graduates from college does not use data mining techniques that use data on alumni grades. However, in this study, the probability of graduation is calculated from the remaining subjects that have not graduated or have not been taken by an active student.

\section{METHODS}

Stages of this research refer to the two stages of the prototype model system development method as shown in Fig. 1.

1) User requirement. This stage is the stage of collecting the data needed for the system/application by analyzing existing applications.

2) This stage is designing algorithms and conducting simulations by creating a feature to calculate the potential time of students' graduation in the student grade recapitulation application.

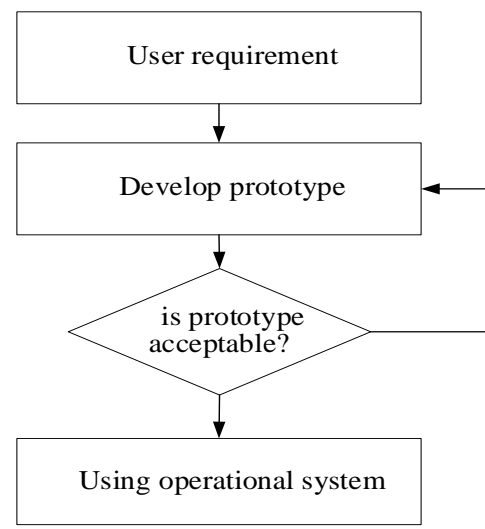

Fig. 1. Prototype Model [12].

\section{RESULTS}

At this stage, an analysis of the guardianship system procedure is carried out. The description of the guardianship process in the ongoing system is described in Fig. 2.

By knowing the guardianship procedure in the current system, it is known that guardian students and lecturers only use the history of course scores as material for course planning, thus allowing for errors in taking courses because they are not supported by a list of courses that have not been taken. In addition, the guardian lecturer cannot see the data of students who have the potential to graduate not on time so that in general there is no attention and effort to direct students to graduate on time.

The second stage is designing an algorithm to determine the potential time of student graduation and making an application for simulation or testing of the algorithm. In making the algorithm, considering the database structure of the running system. The current system database structure can be seen in Fig. 3.

The results of algorithm to calculate possibility of student graduation time are as follows:

1. Find student grade data in the database based on student ID. Store / display index data (code, subject, credit, semester, index, weight) in table / variable index while (T1)

2. Search curriculum data according to student data. Save / display curriculum data in tables / variables of temporary subjects (T2) (code, subject, credit, semester, index, weight)

3. Fill in the index and weight attributes in table $\mathrm{T} 2$ from table T1

4. Filter subjects with an E or Null index in table T2 and save it to the odd semester index table (T3) and even semester value table (T4)

5. Create four tables / variables (T5a-T5d) to store the distribution data for odd semester courses and create four tables / variables (T6a-T6d) to store distribution data for even semester courses. Allocate subjects in table T3 to odd semester tables (T5a-T5d) and table T4 to even semester tables (T6a-T6d) and adjust them to the number of credits.

6. Count the number of tables containing the subjects in T5aT5d and T6a-T6d to find out the number of semesters that still have to be taken.

7. Display information about potential graduation time and information about whether or not to graduate on time.

The following is an example of applying the algorithm to calculate the potential time student to graduation.

1) Search student grade data in the database based on student ID. Save / Display value data (code, courses, credit, semester, Index, weight) in the temporary value table / variable (T1).

To accommodate the search result value data, prepare a 2 dimensional array variable or table component (such as the table component in java SE) with a structure as in Table I. 


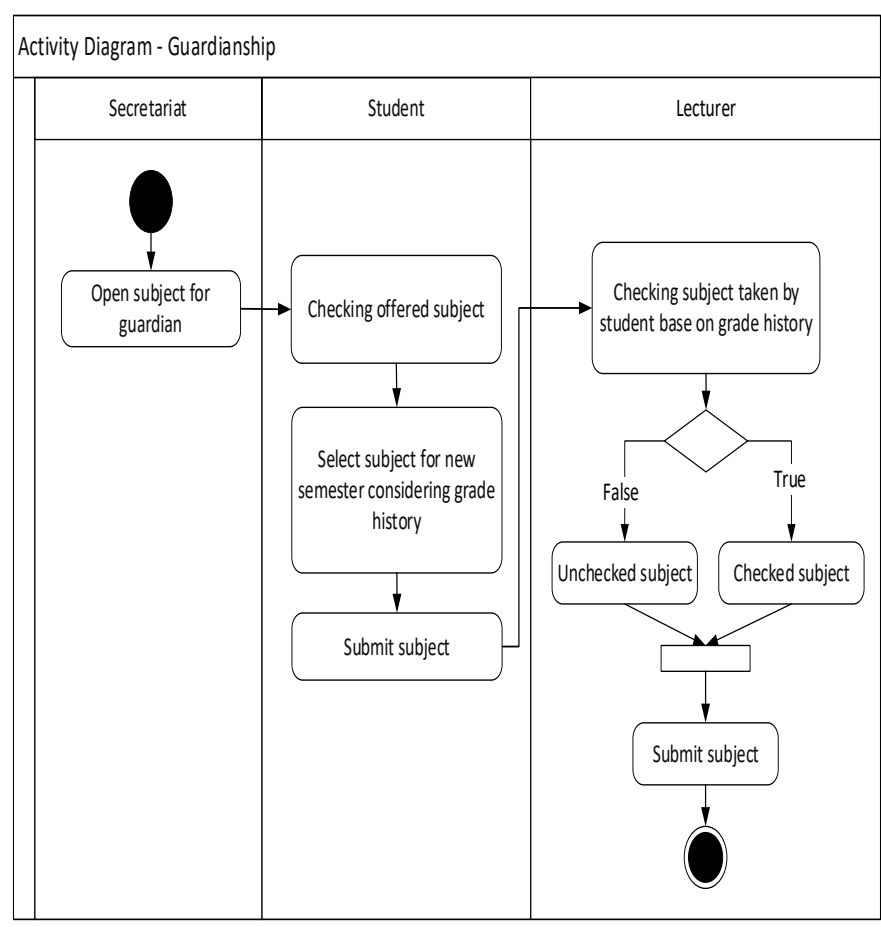

Fig. 2. Guardianship Procedure.

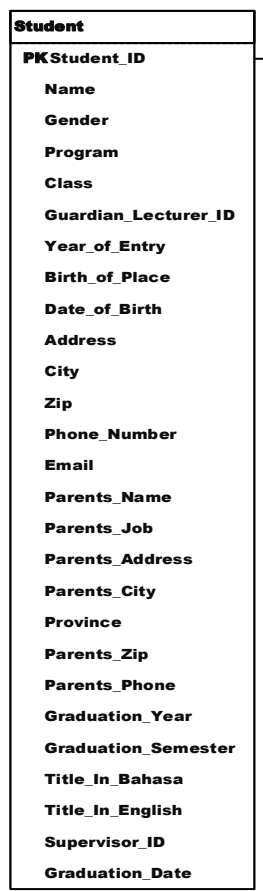

Fig. 3. Database of Grade Recapitulation Application [13].

2) Search curriculum data according to student data. Save / display curriculum data in tables / variables of temporary subjects (T2) (code, subject, credit, semester, index, weight)

After the first process is complete, continue by taking the curriculum data then store / display it with a structure like in stage 1, but the Index and weight are empty. Example of storing / displaying course data as in Table II.
TABLE I. EXAMPLE OF TABLE/VARIABLE TEMPORARY GRADE (T1)

\begin{tabular}{|l|l|l|l|l|l|l|}
\hline No. & Code & Subject & Credit & Semester & Index & Weight \\
\hline 1 & 001 & Subject 1 & 3 & 1 & A & 4 \\
\hline 2 & 002 & Subject 2 & 3 & 1 & E & 0 \\
\hline 3 & 003 & Subject 3 & 2 & 1 & B & 3 \\
\hline$\ldots$ & & & & & & \\
\hline 7 & 007 & Subject 7 & 3 & 2 & E & 0 \\
\hline 8 & 008 & Subject 8 & 3 & 2 & C & 2 \\
\hline 9 & 009 & Subject 9 & 3 & 2 & D & 1 \\
\hline$\ldots$ & & & & & & \\
\hline
\end{tabular}

TABLE II. EXAMPLE OF TABLE/VARIABLE TEMPORARY SUBJECT (T2)

\begin{tabular}{|l|l|l|l|l|l|l|}
\hline No. & Code & Subject & Credit & Semester & Index & Weight \\
\hline 1 & 001 & Subject 1 & 3 & 1 & & 0 \\
\hline 2 & 002 & Subject 2 & 3 & 1 & & 0 \\
\hline 3 & 003 & Subject 3 & 2 & 1 & & 0 \\
\hline.. & & & & & & \\
\hline 7 & 007 & Subject 7 & 3 & 2 & & 0 \\
\hline 8 & 008 & Subject 8 & 3 & 2 & & 0 \\
\hline 9 & 009 & Subject 9 & 3 & 2 & & 0 \\
\hline$\ldots$ & & & & & & \\
\hline 14 & 014 & Subject 14 & 2 & 3 & & 0 \\
\hline 15 & 015 & Subject 15 & 3 & 3 & & 0 \\
\hline 16 & 016 & Subject 16 & 3 & 3 & & 0 \\
\hline$\ldots$ & & & & & & \\
\hline
\end{tabular}

3) Fill in the index and weight attributes on $\mathrm{T} 2$ from $\mathrm{T} 1$ : After the value data (T1) and subject data (T2) are available in the temporary variables / tables, do the process of filling in the index and weight in table $\mathrm{T} 2$ from the index and weight in table T1. Examples of filling in index and weight are as in Table III.

TABLE III. FILL IN INDEX AND WeIGHT AT T2

\begin{tabular}{|l|l|l|l|l|l|l|}
\hline No. & Code & Subject & Credit & Semester & Index & Weight \\
\hline 1 & 001 & Subject 1 & 3 & 1 & A & 4 \\
\hline 2 & 002 & Subject 2 & 3 & 1 & E & 0 \\
\hline 3 & 003 & Subject 3 & 2 & 1 & B & 3 \\
\hline.. & & & & & & \\
\hline 7 & 007 & Subject 7 & 3 & 2 & E & 0 \\
\hline 8 & 008 & Subject 8 & 3 & 2 & C & 2 \\
\hline 9 & 009 & Subject 9 & 3 & 2 & D & 1 \\
\hline$\ldots$ & & & & & & \\
\hline 14 & 014 & Subject 14 & 2 & 3 & & 0 \\
\hline 15 & 015 & Subject 15 & 3 & 3 & & 0 \\
\hline 16 & 016 & Subject 16 & 3 & 3 & & 0 \\
\hline$\ldots$ & & & & & & \\
\hline
\end{tabular}


4) Filter subjects with an E or Null value in table T2 and save it to the odd semester value table (T3) and even semester value table (T4).

The next stage is to prepare two new tables / variables, namely the odd semester table (T3) and the even semester table (T4) to store / display subjects with E or Null index. Separate subjects worth E or Null according to the semester. Save odd semester subjects to table T3 and even semester subjects save to table T4. An example of the results of stage 4 is in Tables IV and V.

5) Make four tables / variables (T5a-T5d) to store the distribution data for odd semester courses and create four tables / variables (T6a-T6d) to store distribution data for even semester subjects. Allocate subjects in table T3 to odd semester tables (T5a-T5d) and table T4 to even semester tables (T6aT6d) and adjust them to the number of credits.

At this stage prepare four tables / variables (T5a-T5d) to store the odd semester Subjects and four tables / variables (T6a-T6d) to store even semester subjects. In this study, the rules for allocating subjects are based on the order of the smallest to the largest semesters, the credit package quota is met. An example of the results of this stage can be seen in Tables VI to XIII.

6) Count the number of tables filled in odd and even semesters to determine the number of semesters that still have to be completed.

TABLE IV. EXAMPLE OF TABLE OF SUBJECT WITH E INDEX AND NULL IN ODD SEMESTER (T3)

\begin{tabular}{|l|l|l|l|l|l|l|}
\hline No. & Code & Subject & Credit & Semester & Index & Weight \\
\hline 1 & 002 & Subject 2 & 3 & 1 & E & 0 \\
\hline 2 & 014 & Subject 14 & 3 & 3 & & 0 \\
\hline 3 & 015 & Subject 15 & 3 & 3 & & 0 \\
\hline 4 & 016 & Subject 16 & 3 & 3 & & 0 \\
\hline$\ldots$ & & & & & & \\
\hline 13 & 051 & Subject 51 & 2 & 7 & & 0 \\
\hline 14 & 052 & Subject 52 & 3 & 7 & & 0 \\
\hline 15 & 053 & Subject 53 & 3 & 7 & & 0 \\
\hline
\end{tabular}

TABLE V. EXAMPLE OF TABLE WITH SUBJECT WITH INDEX E AND NULL IN EVEN SEMESTER (T4)

\begin{tabular}{|l|l|l|l|l|l|l|}
\hline No. & Code & Subject & Credit & Semester & Index & Weight \\
\hline 1 & 007 & Subject 7 & 3 & 2 & E & 0 \\
\hline 2 & 023 & Subject 23 & 3 & 4 & & 0 \\
\hline 3 & 024 & Subject 24 & 3 & 4 & & 0 \\
\hline 4 & 025 & Subject 25 & 3 & 4 & & 0 \\
\hline$\ldots$ & & & & & & \\
\hline 18 & 057 & Subject 57 & 3 & 8 & & 0 \\
\hline 19 & 058 & Subject 58 & 2 & 8 & & 0 \\
\hline 20 & 059 & Subject 59 & 3 & 8 & & 0 \\
\hline
\end{tabular}

TABLE VI. $\quad 1^{\mathrm{ST}}$ ODD SEMESTER TABLE (T5A)

\begin{tabular}{|l|l|l|l|l|l|l|}
\hline No. & Code & Subject & Credit & Semester & Index & Weight \\
\hline 1 & 002 & Subject 2 & 3 & 1 & E & 0 \\
\hline 2 & 014 & Subject 14 & 3 & 3 & & 0 \\
\hline 3 & 015 & Subject 15 & 3 & 3 & & 0 \\
\hline 4 & 016 & Subject 16 & 3 & 3 & & 0 \\
\hline 5 & 030 & Subject 30 & 2 & 5 & & 0 \\
\hline 6 & 031 & Subject 31 & 3 & 5 & & 0 \\
\hline
\end{tabular}

TABLE VII. $\quad 2^{\mathrm{ND}}$ ODD SEMESTER TABLE (T5B)

\begin{tabular}{|l|l|l|l|l|l|l|}
\hline No. & Code & Subject & Credit & Semester & Index & Weight \\
\hline 1 & 033 & Subject 33 & 3 & 5 & & 0 \\
\hline 2 & 034 & Subject 34 & 3 & 5 & & 0 \\
\hline 3 & 035 & Subject 35 & 3 & 5 & & 0 \\
\hline 4 & 047 & Subject 47 & 2 & 7 & & 0 \\
\hline 5 & 048 & Subject 48 & 3 & 7 & & 0 \\
\hline 6 & 049 & Subject 49 & 3 & 7 & & 0 \\
\hline
\end{tabular}

TABLE VIII. $\quad 3^{\text {RD }}$ ODD SEMESTER TABLE (T5C)

\begin{tabular}{|l|l|l|l|l|l|l|}
\hline No. & Code & Subject & Credit & Semester & Index & Weight \\
\hline 1 & 051 & Subject 51 & 2 & 7 & & 0 \\
\hline 2 & 052 & Subject 52 & 3 & 7 & & 0 \\
\hline 3 & 053 & Subject 53 & 3 & 7 & & 0 \\
\hline
\end{tabular}

TABLE IX. $\quad 4^{\mathrm{TH}}$ ODD SEMESTER TABLE (T5D)

\begin{tabular}{|l|l|l|l|l|l|l|}
\hline No. & Code & Subject & Credit & Semester & Index & Weight \\
\hline 1 & & & & & & \\
\hline 2 & & & & & & \\
\hline$\ldots$ & & & & & & \\
\hline
\end{tabular}

TABLE X. $\quad 1^{\text {ST }}$ EVEN SEMESTER TABLE (T6A)

\begin{tabular}{|l|l|l|l|l|l|l|}
\hline No. & Code & Subject & Credit & Semester & Index & Weight \\
\hline 1 & 007 & Subject 7 & 3 & 2 & E & 0 \\
\hline 2 & 023 & Subject 23 & 3 & 4 & & 0 \\
\hline 3 & 024 & Subject 24 & 3 & 4 & & 0 \\
\hline 4 & 025 & Subject 25 & 3 & 4 & & 0 \\
\hline 5 & 026 & Subject 26 & 2 & 4 & & 0 \\
\hline 6 & 027 & Subject 27 & 3 & 4 & & 0 \\
\hline 7 & 028 & Subject 28 & 3 & 4 & & 0 \\
\hline
\end{tabular}

Based on the example of Tables VI to XIII, it can be counted that there are six semesters whose table contains the subject. So, it can be concluded that the number of semesters that must be taken is six semesters. 
TABLE XI. $\quad 2^{\mathrm{ND}}$ EVEN SEMESTER TABLE (T6B)

\begin{tabular}{|l|l|l|l|l|l|l|}
\hline No. & Code & Subject & Credit & Semester & Index & Weight \\
\hline 1 & 038 & Subject 38 & 3 & 6 & & 0 \\
\hline 2 & 039 & Subject 39 & 3 & 6 & & 0 \\
\hline 3 & 040 & Subject 40 & 3 & 6 & & 0 \\
\hline 4 & 041 & Subject 41 & 3 & 6 & & 0 \\
\hline 5 & 042 & Subject 42 & 2 & 6 & & 0 \\
\hline 6 & 043 & Subject 43 & 3 & 6 & & 0 \\
\hline 7 & 044 & Subject 44 & 3 & 6 & & 0 \\
\hline
\end{tabular}

TABLE XII. $\quad 3^{\text {RD }}$ EVEN SEMESTER TABLE (T6C)

\begin{tabular}{|l|l|l|l|l|l|l|}
\hline No. & Code & Subject & Credit & Semester & Index & Weight \\
\hline 1 & 054 & Subject 54 & 3 & 8 & & 0 \\
\hline 2 & 055 & Subject 55 & 3 & 8 & & 0 \\
\hline 3 & 056 & Subject 56 & 3 & 8 & & 0 \\
\hline 4 & 057 & Subject 57 & 3 & 8 & & 0 \\
\hline 5 & 058 & Subject 58 & 2 & 8 & & 0 \\
\hline 6 & 059 & Subject 59 & 3 & 8 & & 0 \\
\hline
\end{tabular}

TABLE XIII. $\quad 4^{\mathrm{TH}}$ EVEN SEMESTER TABLE (T6D)

\begin{tabular}{|l|l|l|l|l|l|l|}
\hline No. & Code & Subject & Credit & Semester & Index & Weight \\
\hline 1 & & & & & & \\
\hline 2 & & & & & & \\
\hline$\ldots$ & & & & & & \\
\hline
\end{tabular}

7) Display information about potential graduation time and information on whether to graduate on time or not on time.

To find out the potential time for graduating from college and information on whether to graduate on time or not on time, it can be done by adding the six semesters to the current semester position. If now in semester 3 then $3+6$ is 9 , meaning that the potential time to pass is in semester 9 . Because the graduation time is in the 9th semester, the information displayed is not graduating on time because the rule on time is if you graduate in semester 8.

That's the algorithm design stage to calculate the probability of students to graduate from college. The next step is to create a feature to calculate the potential time for graduating from college in the student grade recapitulation application using the algorithm. Then the test is carried out to calculate the length of the function process to calculate the potential time to graduate students by inserting the function timer counter code.

The following are the results of testing on the algorithm applied to calculate the potential time of graduate students in 10 times, can be seen in Table XIV.
TABLE XIV. ALgorithm Testing Result

\begin{tabular}{|l|l|}
\hline Test Time & Time (in Second) \\
\hline 1 & 0,187 \\
\hline 2 & 0,155 \\
\hline 3 & 0,160 \\
\hline 4 & 0,139 \\
\hline 5 & 0,182 \\
\hline 6 & 0,182 \\
\hline 7 & 0,137 \\
\hline 8 & 0,158 \\
\hline 9 & 0,202 \\
\hline 10 & 0,150 \\
\hline average & 0,165 \\
\hline
\end{tabular}

\section{CONCLUSION}

Based on the simulation results of the algorithm implementation, information on the number of semesters that must be taken to graduate from college, the courses that can be taken in each semester and information on the possibility for passing on time or not on time. And based on testing by applying the prototype application to produce this information, it takes an average layout time in 0.165 seconds.

\section{ACKNOWLEDGMENT}

This research project is supported by Directorate of Research and Community Service, Ministry of Education and Culture of Indonesia in 2020 Fiscal Year.

\section{REFERENCES}

[1] H. Yue and X. Fu, "Rethinking Graduation and Time to Degree: A Fresh Perspective," Res. High. Educ., vol. 58, no. 2, pp. 184-213, 2017.

[2] K. S. Lockeman and L. E. Pelco, "The Relationship between ServiceLearning and Degree Completion," Michigan J. Community Serv. Learn., vol. 20, no. 1, pp. 18-30, 2013.

[3] N. K. D. Ariani, I. W. Sumarjaya, and T. Bagus Oka, "Analisis FaktorFaktor Yang Memengaruhi Waktu Kelulusan Mahasiswa Dengan Menggunakan Metode Gompit (Studi Kasus: Mahasiswa Fakultas MIPA Universitas Udayana)," E-Jurnal Mat., vol. 2, no. 3, p. 40, Aug. 2013.

[4] W. Widarto, "Faktor Penghambat Studi Mahasiswa yang Tidak Lulus Tepat Waktu di Jurusan Pendidikan Teknik Mesin FT UNY," J. Din. VOKASIONAL Tek. MESIN, vol. 2, no. 2, p. 127, Oct. 2017.

[5] I. A. S. Padmini, L. P. Suciptawati, and M. Susilawati, "Analisis Waktu Kelulusan Mahasiswa Dengan Metode Chaid (Studi Kasus: Fmipa Universitas Udayana)," E-Jurnal Mat., vol. 1, no. 1, 2012.

[6] M. W. Amelia, A. S. M. Lumenta, and A. Jacobus, "Prediksi Masa Studi Mahasiswa dengan Menggunakan Algoritma Naïve Bayes," J. Tek. Inform., vol. 11, no. 1, 2017.

[7] A. Rakhman, "Prediksi Ketepatan Kelulusan Mahasiswa Menggunakan Metode Decision Tree Berbasis Particle Swarm Optimation (PSO)," Smart Comp Jurnalnya Orang Pint. Komput., vol. 6, no. 1, pp. 193-197, 2017.

[8] M. I. Zulfa, A. Fadli, and Y. Ramadhani, "Classification model for graduation on time study using data mining techniques with SVM algorithm," in AIP Conference Proceedings, 2019, vol. 020006, no. 2019. 
[9] V. Riyanto, A. Hamid, and R. Ridwansyah, "Prediction of Student Graduation Time Using the Best Algorithm," Indones. J. Artif. Intell. Data Min., vol. 2, no. 1, pp. 1-9, Mar. 2019.

[10] A. S. Hoffait and M. Schyns, "Early detection of university students with potential difficulties," Decis. Support Syst., vol. 101, pp. 1-11, 2017.
[11] J. S. Bassi, E. G. Dada, A. A. Hamidu, and M. D. Elijah, "Students Graduation on Time Prediction Model Using Artificial Neural Network,” IOSR J. Comput. Eng., vol. 21, no. 3, pp. 28-35, 2019.

[12] R. McLeod and G. Schell, Sistem Informasi Manajemen. Jakarta: Indeks, 2004.

[13] S. Mauluddin and R. Sidik, "Reverse Engineering in Student Mark Recapitulation Application," in IOP Conference Series: Materials Science and Engineering, 2019, vol. 662, no. 2. 